doi: 10.29359/BJHPA.2021.Suppl.2.13

\title{
People with disabilities in sport - Legal aspects of unethical performance enhancement in Paralympics
}

\author{
Jakub Zwierzchowski \\ Faculty of Law and Administration, University of Silesia, Katowice, Poland
}

\section{abstract}

In this viewpoint letter to the Editorial Board, author informs about international conference "People with Disabilities in Sport: Theory and Practice" held on 20th-21st of May 2021 in the Jerzy Kukuczka Academy of Physical Education. Additional subject of the letter raises the issue of discussion on the legal aspects of unethical behavior in Paralympic sports and current challenges in adjusting the legal framework for doping, "boosting" and "techno-doping" under the International Paralympic Committee.

Keywords: paralympic, law, performance enhancement, doping, boosting, techno-doping.

\section{article details}

Article statistics:

Full-text PDF:

ord count: 828; Tables: 0; Figures: 0; References: 5

Received: October 2021; Accepted: October 2021; Published: December 2021

Copyright

Indexation:

http://www.balticsportscience.com

(c) Gdansk University of Physical Education and Sport, Poland

Celdes, Clarivate Analytics Emerging Sources Citation Index (ESCI), CNKI Scholar (China National Knowledge Infrastructure), CNPIEC, DOAJ, EBSCO - Central \& Eastern European Academic Source, EBSCO - SPORTDiscus, EBSCO Discovery Service, Google Scholar, Index Copernicus, J-Gate, Naviga (Softweco, Primo Central (ExLibris), ProQuest - Family Health, ProQuest - Health \& Medical Complete, ProQuest - Illustrata: Health Sciences, ProQuest Nursing \& Allied Health Source, Summon (Serials Solutions/ProQuest, TDOne (TDNet), Ulrich's Periodicals Directory/ ulrichsweb, WorldCat (OCLC)

Funding: This research received no specific grant from any funding agency in the public, commercial, or not-for-profit sectors. Authors have declared that no competing interest exists. Jakub Zwierzchowski; e-mail: jakub.zwierzchowski@us.edu.pl

This is an open access article distributed under the terms of the Creative Commons Attribution-Non-Commercial-NoDerivatives 4.0 International (https://creativecommons.org/licenses/by-nc-nd/4.0/), which permits use, distribution, and reproduction in any medium, provided the original work is properly cited, the use is non-commercial and is otherwise in compliance with the license. 


\section{DEAR EDITORS OF BALTIC JOURNAL OF HEALTH AND PHYSICAL ACTIVITY}

On May 20th - 21st 2021, the 4th International Scientific Conference "People with Disabilities in Sport: Theory and Practice" was held in the Jerzy Kukuczka Academy of Physical Education. This is another edition of the event which creates a platform for domestic and international practitioners and scholars to discuss prospects and challenges in adaptive sports. Topics undertaken during plenary sessions dealt with the issues of people with disabilities in sports in a holistic and an applicational manner. During the conference, many interesting issues concerning Paralympic sports and their constant evolution were presented, both from a medical, training process, nutritional, psychological and legal perspectives.

Contemporary adapted sport has become a platform that enables athletes with disabilities not only to compete at the highest level, but also to practice sports professionally. Professionalization of para-sports leads to competitiveness that requires achieving better results and these directly affect para-athletes' socio-economic status. Due to the specifics of adaptive sports, performance enhancement (PE) is a much more multi-layered controversy than in its Olympic counterpart. Unethical manner of enhancing performance in Paralympic sports can be achieved not only by doping, but also by "boosting" (Autonomic Dysreflexic state) and "techno-doping" (use of the advanced equipment).

Concerning doping, the International Paralympic Committee (IPC) applies its own AntiDoping Code (IPC Code) [1] which is, in a way, a mirror image of the regulations adopted by the World Anti-Doping Agency (WADA) within the World Anti-Doping Code [2]. The legal mechanisms and instruments are in no way adjusted [see 3], despite the fact that parasport does not play by the same rules, and para-athletes have different specifics than Olympic athletes. Boosting and its control is not mentioned within the IPC Code (it is, however, mentioned under the Paralympic Committee Handbook [4]) and its recognition as being a subject to the anti-doping regime could only be interpreted due to the existence of the WADA Prohibited List ${ }^{1}$.

Beside the importance of the classification system, which was introduced during the Conference by W. Gawroński, $\mathrm{PhD}$, one can find another separate and fundamental challenge for para-sport - the use of technologically advanced equipment - "techno-doping". I would like to draw Readers' attention to the consequences of technological advancement directly affecting performance in Paralympic sports. It should become a subject of the interdisciplinary discussion, including its legal prospects. The topic of "techno-doping" and use of equipment in the context of diagnosis of athletes with disabilities was referred to during the special plenary session of the Conference by the speakers from the Silesian University of Technology, prof. Z. Paszenda, PhD, and prof. M. Gaździk, PhD.

Currently, there is a vague medical, ethical, and legal indication of what "performance enhancer" and "performance enabler" are. Generally, for certain disciplines of adaptive sports, equipment is condicio sine qua non just to enable performance. The principles on equipment, adopted and defined by the IPC ${ }^{2}$, are general and vague, thus potentially leading to disputes. Whether to include "techno-doping" within the anti-doping regulations under IPC Code is an open discussion. Nonetheless, from the internal perspective of technodoping, IPC principles applied to the apparatus used by para-athletes are open to abuse. I am convinced, there is a need for a discussion to clearly differentiate what should be

1 Point M1.3 states that "any form of intravascular manipulation of the blood or blood components by physical or chemical means", which indirectly indicates that boosting could be considered as a prohibited method under anti-doping regulations [1]. 
considered unethical PE in parasport, thus distinguishing "performance enhancement" from "performance enabler" and defining these concepts under the legal framework of IPC.

The currently binding legal framework introduced by IPC and International Sports Federations - anti-doping rules, policies and technical regulations - is not adjusted enough to cope with the challenges posed by contemporary PE in parasports.

\section{REFERENCES}

[1] International Paralympic Committee Anti-Doping Code, effective as of 1st of January 2021 [available at: https://www.paralympic.org/antidoping, last access: 17.10.2021].

[2] The World Anti-doping Code International Standard Prohibited List effective as of 1st of January 2021 [available at: www.wada-ama.org, last access: 17.10.2021].

[3] Therapeutical Use Exemption as a legal instrument remains the same in both IPC Code and WADA Code. This leads to a dispute under Court of Arbitration for Sport, Arbitration CAS 2015 / A / 4355 J. \& Anti Doping Denmark (ADD) v. International Paralympic Committee (IPC), award of 26 of May 2016 (operative part of 18 March 2016) [available at: https://jurisprudence.tas-cas.org/Shared\%20Documents/4355.pdf, last access: 17.10.2021].

[4] Paralympic Committee Handbook, Section 2: Rules, Regulations, Codes and Policies, Chapter 4.2 - Position Statement on Autonomic Dysreflexia and Boosting, April 2016 [available at: https://www.paralympic.org/ipc-handbook, last access: 17.10.2021].

[5] International Paralympic Committee Handbook, Section 2: Rules, Regulations, Codes and Policies, Chapter 3.10 - IPC Policy on Sport Equipment, approved on 2nd of April 2011 [available at: https://www.paralympic.org/ipc-handbook, last access: 17.10.2021]. 